\title{
A hozzáadottérték-adó (áfa) gyakorlata az európai adójog (az EUB esetjoga), valamint a nemzeti adójog (a magyar közigazgatási bírósági gyakorlat) kölcsönhatásában
}

\section{The Judicial Practice on Value Added Taxation (VAT) in the Interactions between the European Tax Law (the Case Law of the European Court of Justice) and National Tax Law (the Jurisprudence of the Hungarian Administrative Courts)}

A jelen tanulmány célja, hogy áttekintést nyújtson arról, hogy a magyar bíróságok előzetes döntéshozatali kérelmeik útján miként járultak hozzá az európai héaszabályok értelmezésének alakitásához. Az európai héaszabályozás jelenlegi rendszere semleges és összetett, továbbá számos résztvevője van. Mindazonáltal a héarendszer egy gyorsan fejlődö terület, amely az utóbbi időkben olyan új témaköröket vet fel, mint például a héakötelezettség megfordulása és annak a szankciók arányosságára vonatkozó követelményre gyakorolt hatása. Egy kérdésekre és válaszokra épülő folyamatos párbeszéd figyelhetö meg, hiszen az újabb adóügyekben megfogalmazott kérdések gyakorta a korábbi ügyekben adott válaszok kapcsán merülnek fel. Az Európai Unió Bíróságát a múltban és a jelenben egyaránt foglalkoztató kérdések között szerepel a számla címzettjének felelössége, az adósemlegesség és az adókijátszás elleni küzdelem közötti konfliktus, valamint a nemzeti és az európai uniós szint közötti hatáskörmegosztás. Számos magyar vonatkozású ügy tekinthető fontos építökönek a Bíróság esetjogának fejlesztése szempontjából.

Darák Péter a Kúria elnöke, az ELTE ÁJK oktatója, Pénzügyi Jogi Tanszék. E-mail: darak.peter@ajk. elte.hu 
Kulcsszavak: nemzeti és európai uniós héaszabályozás, előzetes döntéshozatal, adólevonás, adóvisszatérítés, szankciók arányosságának elve, adósemlegesség, adókijátszás

The present paper aims to give an overview on the contribution of the Hungarian courts in the form of preliminary references to the shaping of the interpretation of the European VAT rules. The current system of the European VAT is neutral and complex, and it involves several actors. However, the VAT system is a quickly developing field, new questions such as the one related to reverse VAT and its impact or the proportionality of sanctions have recently arisen. A cycle of questions and answers can be observed, as questions emerging in new tax cases are often built upon previous cases. The European Court of Justice had and still has to address issues like the responsibility of the invoice recipient, the conflict between tax neutrality and combating tax evasion, as well as the allocation of competences between national and EU levels. Many of the Hungarian cases can be considered important brickstones in developing the case law of the Court.

Keywords: national and European VAT regulation, preliminary ruling, tax deduction and reimbursement, proportionality of sanctions, tax neutrality, tax evasion

\section{Bevezetés}

Aki arra vállalkozik, hogy a hozzáadottérték-adó (a továbbiakban: héa) müködéséről készítsen elemzést, nem teheti ezt az örök érvényưség igényével. (Weber-Grellet, 2001:113) Sokkal inkább annak tudatában járhat el, hogy következtetései csak belátható időn belül érvényesek. (Peeters, 2005:26)

Ennek a jelenségnek az egyik oka az európai hozzáadottérték-rendszer átmeneti jellege, amely lényegében 1992 óta harmonizációs és jogalkotói késedelmet szenved az uniós tagállamok egyes csoportjainak eltérő, sőt ellentétes gazdasági értékei miatt. (Terra-Wattel 2008:147-155) A másik oka, hogy az adóelkerülés elleni küzdelem erősödő intézkedései több oldalról is támadják a héarendszer semlegességének elvét. (Widman, 2015:756-873) Nem véletlen, hogy a jelentős gazdasági erővel rendelkező országok (Franciaország, Németország, Hollandia) jogi szakirodalma vaskos kommentárokkal és esetjoggyújteményekkel támogatja az adójog alkalmazóit értelmezési nehézségeikben. (Simon, 2012:299)

Jól mutatja az egymásra épülő többszereplős struktúra sajátosságait az Európai Bíróság (a továbbiakban: Bíróság vagy EUB) elnökének 2016. április 21-i végzése, ${ }^{1}$ amely a Kúria elözetes döntéshozatali kérelme tárgyában keletkezett ügyet törölte, mert az eljárásban részt vevő felek egyező álláspontra jutottak, és a bíróság határozata így szükségtelenné vált. Továbbá az Európai Bíróság elnökének 2018. június 26-án kelt végzése ${ }^{2}$ is jól mutatja a sajátosságokat, mivel eszerint a Bíróság elnöke a főtanácsnok

C-114/16 sz. Damien Zöldség, Gyümölcs Kereskedelmi és Tanácsadó Kft.-ügy [ECLI:EU:2016:317].

C-173/18 sz. FS-ügy [ECLI:EU:C:2018:578]. 
meghallgatását követően elrendelte az ügy törlését, mert a Bíróság hivatalának felhívására az előterjesztő Szombathelyi Közigazgatási és Munkaügyi Bíróság közölte, hogy előzetes döntéshozatal iránti kérelmét az időközben meghozott 2018. május 17-i Vámosítéletre ${ }^{3}$ figyelemmel nem szándékozik fenntartani.

$\mathrm{Az}$ ismertetett eljárásjogi csavar (a nemzeti bíróság kérdést terjeszt elő az Európai Bírósághoz, időközben más ügyben döntést hoz az Európai Bíróság, a nemzeti bíróság visszavonja a kérdését) arra utal, hogy itt párhuzamos ügyekben formálódó koherens jogértelmezési rendszerrel állunk szemben, ahol egy román vagy lengyel ügyben is születhet a magyar bíróságok számára használható konklúzió.

\section{Pillanatfelvétel a 2019-ben nyitott jogértelmezési kérdésekben feltárható uniós héagyakorlatról}

Az Európai Bíróság 2019. április 11-én a PORR-ügyben hozott ítéletében ${ }^{4}$ az uniós jogot, valamint az adósemlegesség és a tényleges érvényesülés elvét úgy értelmezte, hogy azokkal nem ellentétes az olyan adóhatósági gyakorlat, amely megtagadja a héalevonás jogát olyan számla alapján, amelyet fordított adózás hatálya alá tartozó ügylet esetén az általános szabályok szerint állítottak ki anélkül, hogy az adóhatóság megelőzően megvizsgálná, hogy a számlakibocsátó vissza tudja-e téríteni a számla címzettjének a jogalap nélkül megfizetett héaösszegét, illetve tudja-e helyesbíteni ennek érdekében a számlát vagy maga térítené vissza a befizetett adót.

A Bíróság ugyanakkor hangsúlyozta, hogy amennyiben a héa visszatérítése lehetetlenné vagy rendkívül nehézzé válik, lehetővé kell tenni, hogy azt a vállalkozó közvetlenül az adóhatóságtól kérhesse.

$\mathrm{Az}$ ismertetett ítélet a legutóbbi építőkocka abban a jogértelmezési piramisban, amely adózói érdek és a költségvetés bevételi érdeke között kíván harmóniát teremteni. Az ítéletből kiolvasható, hogy az adózó visszatérítési igényének biztosítása érdekében az adóhatóságot nem terheli többleteljárási kötelezettség.

Az EUB 2019. február 13-i Human Operator-ügyben hozott ítéletében ${ }^{5}$ az uniós joggal ellentétesnek minősítette a fordított adózás alkalmazását olyan időpontban, amikor Magyarország még csak kérelmezte az általános szabályoktól való eltérés engedélyezését még abban az esetben is, ha kifejezte az eltérés visszaható hatályú alkalmazására irányuló szándékát. A határozat utal arra, hogy az ilyen típusú uniós határozatok a címzettjük értesítésével lépnek hatályba, ${ }^{6}$ illetve a jogbiztonság és a bizalomvédelem elvére tekintettel az uniós jogi anyagi jogi szabályokat főszabály szerint úgy kell értelmezni, hogy azok a hatálybalépésüket követően keletkezett jogviszonyokra vonatkoznak. ${ }^{7}$

C-566/16 sz. Vámos-ügy [ECLI:EU:C:2018:321].

C-691/17 sz. PORR Építési Kft.-ügy [ECLI:EU:C:2019:327].

C-434/17 sz. Human Operator Zrt.-ügy [ECLI:EU:C:2019:112].

Az ítélet 32. pontja.

Az ítélet 36. pontja. 
Az ítéletből kiolvasható az a szándék, hogy a héairányelv ${ }^{8}$ szabályai az egységes piacon általánosan érvényesüljenek, és az azoktól való eltérő nemzeti szabályozás csak az eltérés engedélyezését követően legyen alkalmazható. Az ítéletben foglalt jogértelmezés a héairányelv elsődlegességét kényszeríti ki.

Az Európai Bíróság 2018. február 22-én kelt Nagyszénás Kft. ügyében hozott ítéletében ${ }^{9}$ a héairányelv hatályát illetően tette világossá, hogy ha egy gazdasági társaság az önkormányzattal kötött szerződés alapján közfeladatot lát el és azt ellenszolgáltatás fejében teljesíti, az héaköteles szolgáltatásnyújtásnak minősül. Az ítélet a közhatalmi és gazdasági tevékenység elhatárolásában nyújt segítséget.

A Bíróság 2018. május 17-én kelt Vámos-ügyben hozott ítélete ${ }^{10}$ szerint nem ellentétes az uniós joggal az olyan nemzeti szabályozás, amely kizárja a kisvállalkozás alanyi adómentességét, amennyiben az adózó a gazdasági tevékenység megkezdésének bejelentésével egyidejúleg nem választotta az alanyi adómentességet. Az ítélet újabb adalék ahhoz a sokrétủ kérdéskörhöz, hogy milyen jelentőséget kell tulajdonítani az adóhatósági nyilvántartásokba történő bejelentkezésnek, regisztrációnak, illetve mennyiben ítélhető meg ettől eltérően az adózó választásának bejelentése.

Az Európai Bíróság 2017. október 12-én kelt Lombard-ügyben hozott ítélete ${ }^{11}$ lízingszerződések alapján fennálló esedékes törlesztő részletek részleges nem fizetése miatti utólagos adóalap-csökkentés vonatkozásában mondta ki, hogy a megszűnés, felmondás, elállás esete megvalósítja azt az uniós szabályt, hogy a lízingbeadó már nem követelheti a lízingdíj megfizetését, a szerződés végleges megszüntetése esetén e szabályra lehet hivatkozni. Az uniós szabály ugyanakkor választási lehetőséget biztosít a tagállamoknak, hogy ez jogosultságot teremt-e az adóalap csökkentésére.

Az ítélet újfent arra hívja fel a figyelmet, hogy az uniós szabályozás bizonyos esetekben kiegészülhet olyan nemzeti szabályokkal, amelyek lényeges feltételeket határoznak meg, például az adóalap csökkenthetősége körében.

A Bíróság 2017. július 6-án kelt Glencore-ügyben hozott ítélete ${ }^{12}$ az uniós joggal ellentétesnek minősíti az olyan nemzeti szabályozást, amely az ellenőrzési eljárás elhúzódása miatt elhalasztja a héakülönbözet visszatérítésének időpontját. Álláspontja szerint az adózó részére fizetendő késedelmi kamat nem fizethető meg túlzottan hosszú adóellenőrzési eljárás esetén, ha az nem az adóalany magatartásának tudható be.

Az ítélet abba a sorba illeszkedik, amely az anyagi jogosultságok és az eljárásjogi helyzetek szövevényes viszonyrendszerében keresi az eljárásjogi szabálytalanságok lehetséges anyagi jogi következményeit.

Az Európai Bíróság 2017. január 12-én kelt $M V M$-ügyben hozott végzésében ${ }^{13}$ úgy határozott, hogy a holdingtársaságban, illetve egyes leányvállalatai érdekében igénybe vett szolgáltatások a héa szempontjából nem minősülnek gazdasági tevékenységnek, ezért azok után előzetesen felszámított héa nem vonható le.

A Tanács 2006/112/EK irányelve (2006. november 28.) a közös hozzáadottértékadó-rendszerről (HL L 347.), 2006.12.11., 1-118.

C-182/17 sz. Nagyszénás Kft.-ügy [ECLI:EU:C:2018:291].

C-566/16 sz. Vámos-ügy [ECLI:EU:C:2018:321].

C-404/16 sz. Lombard Zrt.-ügy [ECLI:EU:C:2017:759].

C-254/16 sz. Glencore Agriculture Hungary Kft.-ügy [ECLI:EU:C:2017:522].

C-28/16 sz. MVM Zrt.-ügy [ECLI:EU:C:2017:7].

Európai Tükör 2019/3. 
A holdingtársaságok héakötelezettsége tárgyában számos európai bírósági határozat tartalmaz megállapításokat. A jelen ügyben a szóban forgó szolgáltatások jellege (különösen üzletrész megszerzésekhez kapcsolódó üzletviteli szolgáltatások) alapján helyezkedett az Európai Bíróság arra az álláspontra, hogy azok nem minősülnek adóköteles gazdasági tevékenységnek.

Az EUB 2017. április 26-án kelt Farkas-ügyben hozott ítélete ${ }^{14}$ a fordított adózás alá eső ügyletre tévesen az általános adózásra esően állítottak ki számlát, amelyre összefüggésben a Bíróság megállapította, hogy amennyiben az állam nem esett el adóbevételtől, és nem merül fel adócsalásra utaló körülmény, aránytalan a héa 50\%-át kitevő bírság kiszabása. Utal azonban arra, hogy ezt a kérdést a nemzeti bíróságnak kell megvizsgálnia. Az ítélet határozottan alkalmazza az arányosság elvét, amikor összekapcsolja a költségvetési érdek sérelmének hiányát és az alkalmazható szankciót.

Az Európai Bíróság 2016. december 15-én kelt Signum-ügyben hozott végzése ${ }^{15}$ az adólevonási jog megtagadásának lehetséges okait értelmezi hangsúlyozva, hogy az adóalanytól nem követelhetőek olyan ellenőrzések, amelyeket nem köteles elvégezni.

Számos EUB-ítélet foglalkozik azzal a kérdéssel, hogy melyek az adóalanytól elvárható észszerû intézkedések annak érdekében, hogy meggyőződjön, nem vesz részt adócsalásban, amelyet az értékesítési lánc korábban eljáró szereplője követ el.

Az Európai Bíróság 2016. június 2-án kelt Lajvér-ügyben meghozott ítélete ${ }^{16}$ olyan adózók tevékenységét minősítette, amelyek csak kiegészítő jelleggel folytathatnak üzletszerű gazdasági tevékenységet, és amelyek állami és uniós forrásokból finanszírozott létesítményeket kezeltek. A Bíróság álláspontja szerint ez gazdasági tevékenységnek minősül, azonban a nemzeti bíróságnak kell tisztáznia a szolgáltatásnyújtások visszterhes jellegét. Az ítélet újabb adalék a héarendszer tárgyi hatályának meghatározásához.

Az Európai Bíróság 2016. december 8-án kelt Stock-ügyben meghozott ítélete ${ }^{17}$ egy olyan összetett ügylet adókötelezettsége, illetve adóalapja vonatkozásában foglalt állást, mint az integrált mezőgazdasági együttműködésre irányuló ügylet. Egyrészt megállapította, hogy az esetleges kiegészítő szolgáltatások nem befolyásolják az ügylet minősítését. Másrészt az adóalapnak részét képezi mind a termékek ára, mind a finanszírozási kölcsön után fizetett kamat. A határozat az összetett és egységes ügyletek héaminősítése vonatkozásában ad támpontokat.

\section{Pillanatfelvétel az uniós joghoz kapcsolódó héaügyek magyar bírói gyakorlatáról}

A Fővárosi Közigazgatási és Munkaügyi Bíróság 2018. március 19-én kelt végzésében ${ }^{18}$ az Európai Bíróság előzetes döntéshozatali eljárását kezdeményezte, hogy vajon

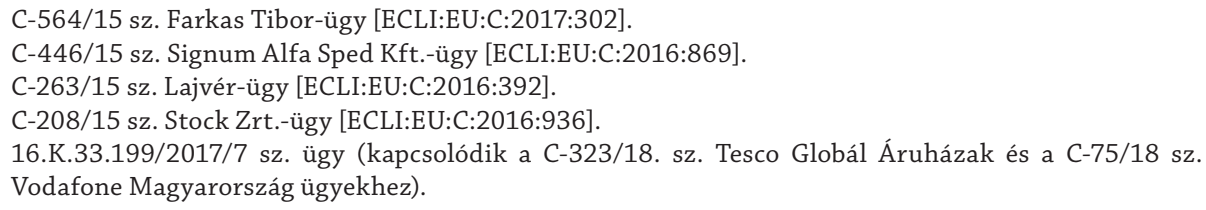

Európai Tükör 2019/3. 
összeegyeztethető-e az uniós joggal a bolti kiskereskedelmi tevékenységet folytató adózó erősen progresszív külön adófizetési kötelezettsége, ha egy gazdasági társaságban több boltot múködtet, míg a franchise-rendszerben múködő belföldi tulajdonú adóalanyok adómentes sávba kerülnek. A végzés arra is választ vár, hogy az uniós jogba ütközés megállapítását külön kérelemmel kell kérni. Az ügy az Európai Unió Bírósága előtt folyamatban van.

A Kúria 2017. március 30-án kelt végzésében ${ }^{19}$ azt kérdezte az Európai Bíróságtól, hogy a 100\%-ban települési önkormányzati tulajdonban álló gazdasági társaság közjog által szabályozott szervezetnek minősül-e, tekinthető-e úgy, mintha hatóságként járna el, illetve a települési önkormányzat által a feladatellátásért fizetett összeg ellenértéknek tekinthető-e. Az Európai Bíróság a választ a fent ismertetett Nagyszénás-ügyben adta meg.

A Nyíregyházi Közigazgatási és Munkaügyi Bíróság 2016. október 26 -án kelt végzésében ${ }^{20}$ arra a kérdésre várt választ, hogy az adóhatóság utólagos adóellenőrzés keretében kizárhatja-e az alanyi adómentesség választásának lehetőségét. Az ügyet a Bíróság Vámos-ügyként vette nyilvántartásba, és hozott abban ítéletet.

A Szegedi Közigazgatási és Munkaügyi Bíróság 2016. július 8-án kelt végzésében ${ }^{21}$ a lízingszerződés felmondása esetére vonatkozó adóalap-csökkentés vonatkozásában intézett kérdést az Európai Bírósághoz. Az Európai Bíróság a választ az előző fejezetben ismertetett Lombard-ügyben adta meg.

A Kúria 2016. február 8-án kelt végzésében ${ }^{22}$ azt a kérdést tette fel az Európai Bíróságnak, hogy köteles-e az adóhatóság az adózó levonási jogát elismerni az adóhatósági ellenőrzés során, amennyiben az adózó bevallásában az előzetes felszámított adó nem szerepel, jóllehet a megfelelő számlák rendelkezésre állnak és az adózó az ellenőrzés során kéri a levonási jog elismerését. A végzés indokolása nem hagy kétséget a Kúria eljáró tanácsának álláspontja felől. Eszerint azért van szükség a feltett kérdések megválaszolására, mert még nem született döntés abban a kérdésben, hogy a héalevonási-jog kizárólag a bevallás benyújtása útján gyakorolható-e. A végzésben írtak szerint, hogyha az adózó az ellenőrzéskor kéri levonási jogának elismerését, és számlái megfelelnek az előírásoknak, úgy e jogosultságát nem lehet azzal elutasítani, hogy nem tett eleget a héairányelv 179. és 250. cikkében foglaltaknak. Amint azt a bevezetőben említettem, az Európai Bíróság nem került döntési helyzetbe, miután a felek a felülvizsgálati eljárásban megegyeztek.

A Kecskeméti Közigazgatási és Munkaügyi Bíróság 2015. október 7-én kelt végzésében ${ }^{23}$ azt kérdezte az Európai Bíróságtól, hogy fordított adózás alá eső ügylet esetében az egyenes adózás szerinti számlakiállítás folytán megfizetett áfalevonási jogával lehet-e élni, illetve arányos-e az 50\%-os mértékű adóbírság, ha a költségvetést nem érte kár.

Kfv.I.35.694/2016/4 sz. ügy (C-182/17. sz. Nagyszénás-ügy [ECLI:EUC:2018:291].

17.K.27.247/2016/16 sz. ügy (C-566/16. sz. Vámos-ügy).

7.K.27.479/2016/5 sz. ügy (C-404/16. sz. Lombard-ügy).

Kfv.I.35.404/2015/9. sz. ügy (C-114/16. sz. Damien-ügy.)

14.K.27.056/2015/16-I sz. ügy (C-564/15. sz. Farkas-ügy).

Európai Tükör 2019/3. 
A kérdésekre az Európai Bíróság a fent ismertetett Farkas-ügyben hozott határozatában adott választ.

A Fővárosi Közigazgatási és Munkaügyi Bíróság 2015. augusztus 10-én kelt végzésében ${ }^{24}$ előzetes döntéshozatali eljárást kezdeményezett abban a kérdésben, hogy mennyiben várható el a számlabefogadótól, hogy a jogügylet körülményeit, a számlakibocsátót ellenőrizze, hogyan értékelhető, ha a gazdasági esemény nem a számlában feltüntetett felek között jött létre, ha csupán formai hiba áll fenn. A kérdésekre az Európai Bíróság a Signum-ügyben hozott határozatában adott választ.

A Kúria 2019. március 7-én kelt végzésében ${ }^{25}$ azt a kérdést intézte az Európai Bírósághoz, hogy ellentétes-e az uniós joggal az a tagállami gyakorlat, amely az adólevonási jog vonatkozásában kizárólag arra van figyelemmel, hogy az adóköteles esemény mikor következett be, és nincs tekintettel arra, hogy a felek között a teljesítés mértéke tekintetében polgári jogi vita áll fenn, amely bírósági útra terelődött, és a számlát csak a jogerős ítéletet követően állították ki. Áttörhető-e a szolgáltatásnyújtás időpontjától számított ötéves elévülési idő, befolyásolja-e a levonási jog gyakorlását a számlabefogadói magatartás, hogy a jogerős ítéletben megállapított vállalkozói díjat csak végrehajtási eljárásban fizették meg, és a számlát emiatt csak az elévülési határidő után állították ki. Az ügy az Európai Unió Bírósága előtt folyamatban van.

\section{Következtetések}

Az ismertetett nagyszámú eset statisztikailag is igazolja, hogy a hozzáadottérték-adó európai és tagállami szabályozása a mindennapos alkalmazás során számtalan jogalkalmazási, jogértelmezési kérdést vet fel. A bíróságok iránymutató döntései részben hiányos vagy hibás jogszabályt pótol, illetve azok hézagos szabályait egészíti ki. A jogalkotási hiányosságokat részben magyarázza az a kényszer, hogy a nagyszámú uniós tagállam érdekeit össze kell hangolni. Részben azonban - ide sorolom az ismertetett ügyek nagyobb részét - a bíróságok szokásos napi tevékenységüket végzik, amikor keresik az alkalmazandó jogot, és értelmezik azt. A héaügyekben az uniós és a nemzeti ügyek egyensúlyban állnak. Ez az egyensúly azonban nem statikus. A kérdések, válaszok, átfogalmazott kérdések és részletesebb válaszok körforgása dinamikus rendszerré teszik az uniós és tagállami igazságszolgáltatást. A kölcsönös visszajelzések rugalmassá teszik a joggyakorlatot, és ha egy-egy meghatározott problémakört vizsgálunk, kifejezett fejlődést láthatunk. (Van Raad, 2012: 2689-4060) Példaként említhető az adóalany és az adóhatóság fegyveregyenlősége, a szankciók arányossága, az alanyi jogosultságok érvényesítése. Egyes kérdések azonban mintha nem jutnának nyugvópontra. Így nem megnyugtató, hogy milyen magatartás várható el a számlabefogadótól, illetve az adósemlegesség és az adóelkerülés elvének ütközése. E kérdések elvszerű tisztázásának hiánya talán az ellentétes irányú jogalkotói szándékok terhére írható, a bíróságokat azonban nem menti fel azon kötelezettségük alól, hogy a gazdasági és adójogi folyamatok megnyugtató rendezésére törekedjenek.

$\begin{array}{ll}24 & \text { 24.K.34.083/2014/24 sz. ügy (C-446/15. sz. Signum-ügy). } \\ 25 & \text { Kfv.I.35.172/2018/7 sz. ügy (C-258/19. sz. Erovia-ügy). }\end{array}$

Európai Tükör 2019/3. 


\section{Felhasznált irodalom}

Peeters, Bruno. ed. (2005): The concept of tax. Amsterdam, IBFD Publications.

Simon István (2012): Pénzügyi jog II. Budapest, Osiris Kiadó.

Terra, Ben J. M. - Wattel, Peter J. (2008): European Tax Law. Fifth Edition, Kluwer Law International.

VAN RAAD, Kees (2012): Materials on International \& EU Tax Law. Vol. 2, Leiden, International Tax Center.

WeBER-GRELlet, Heinrich (2001): Steuern im modernen Verfassungsstaat. Köln.

WidMAN, Werner D. ed. (2015): Veranlagungshandbuch Umsatzsteuer 2014. Institut der Wirtschaftsprüfer, IDW. 